\title{
RELIGIOUS PLURALISM AND RELIGIOUS BELIEF IN VIETNAM TODAY ${ }^{1}$
}

\author{
Nguyen Thi Minh Ngoc \\ Institute of Sociology \\ Vietnam Academy of Social Sciences, Vietnam
}

\begin{abstract}
Vietnam is a communist country. For a Marxist ideologue, "religion is the opium of the masses." But many communist countries-over the years - have evolved from a strictly atheistic persuasion to a tolerance for religious practices. Except probably in North Korea, this transformation from an atheistic perspective to religious tolerance has become a phenomenon in communist countries like Russia and China. Vietnam did not have that experience. This paper will show that religious pluralism was tolerated, even accepted, in communist Vietnam. I will show how vibrant this religious amalgamation is in Vietnam and demonstrate, as in the case of market economics thriving in communist countries, that Vietnamese communism and religious pluralism can robustly coexist with each other.
\end{abstract}

\section{NTRODUCTION}

This paper tackles the phenomenon of religious pluralism in Vietnam today. The first part is discussion of the point of view of Vietnamese state and that of the Communist Party about religion. Because Vietnam is one of the Communist countries, sometime people in other countries have a misunderstanding of the point of view on religion of State and Communist Party. One might ask: What is the religious life in a country where the national ideology is atheism? It should be made clear that there is a religious life in Vietnam. The second part discusses the characteristics of religious pluralism in Vietnam. The third part is about the religious beliefs in Vietnam based on religious pluralism. Finally some concluding remarks.

To substantiate the claim of this paper the author uses the results of the surveys conducted by the Institute for Religious Studies carried out throughout the country from 1993 to 1995 and from 1997 to 1998. These are complemented by the surveys and field research done in five Central Highland, Hanoi and Ninh Binh provinces in Vietnam in 2013 by government researchers and 2014 by the author herself. The major method utilized is documented analysis which covers analysis of quantitative and qualitative data. 


\section{THE RELIGIOUS VIEWPOINT OF THE VIETNAMESE PARTY AND THE STATE}

The religious policy of the Vietnamese government and the Party is based on, on one hand, the basic view of Maxism and Leninism and the ideology of Ho Chi Minh towards religion and beliefs, and on the other hand, the developments in the world, the features of beliefs and religions in Vietnam together with the needs of the revolution at various points of time in the history. Besides, the only one consistent attitude of the Party and the Vietnamese government is to respect the religious freedom of the people, to appreciate religious unity and national harmony. With or without a belief or religion, the people need to watch out against the schemes to undermine the country.

The above mentioned attitude is realized by the policies that suit the needs of particular periods of time. Through the analysis of the characteristics of the beliefs and religions in our country and the lessons learnt from the revolutionary reality, as well as the needs of the cause of renovation, the Party and the government have timely issued the policies that meet the demand of the revolution in the new stage. This is contained in the Party and State documents.

It is written in the political report at the 7th National Party Congress: "Beliefs and religions are the spiritual need of a proportion of the population. The Party and the State respect the freedom to follow and not to follow religions of the people; and exercise the equality between religious and non-religious people; overcome the rigid attitude, prejudice, and discrimination towards religious people; are against the activities that violate the people's religious freedom, and strictly forbid and prevent the exploitation of religions to sabotage the national unity, national independence, socialism, and to prevent the people from exercising their citizen duties" (Communist Party 1991, 78).

It is also written in the Program of Building the Country in the Transition Time to Socialism: "Beliefs and religions constitute the spiritual ne-eds of a proportion of the people. To exercise consistently the policy of respecting the right to religious freedom. Not allowed are the activities against the right to religious freedom and the exploitation of religions to sabotage the benefits of the Nation and the people" (Communist Party, 2017).

The significant policies about religions have been realized through the constitution and laws. As stated in Article 70 of the Constitution of the Socialist Republic of Vietnam promulgated in 1992: "Vietnamese citizens have the right to religious freedom; the right to follow and not to follow a religion. All religions are equal before the law. Worshiping places of religions are protected by the law. It is not allowed to violate the right to religious freedom, to exploit religious freedom to violate the laws and policies of the state" (Communist Party, 1991, p. 159).

The amended Constitution promulgated in 2013 asserts the same thing in Article 24: "1. Everyone has the right to religious freedom, to follow or not to follow a particular religion. All religions are equal before the law. 2. The state respect and protect the right to religious freedom. 3. No one is allowed to violate the right to religious freedom or to exploit religious freedom to violate the laws" (Social Republic of Vietnam, 2013). 
To meet the demands of the renew process, to promote patriotism and to mobilize all potentials and the knowledge of all the people the Party's cause of modernizing and industrializing the country, in various stages of the revolution, the Party and the state promulgate various policies concerning religions. Every time the Party has a new policy, the government would timely legalize it through the legal documents so the policy can be brought to life. Religious practices must aim at promoting the unity of different ethnic groups in the great unity of the whole nation; promote the overall strength of the whole nation, and exercise successfully the cause of modernizing, industrializing and protecting the Nation, aiming at becoming a rich nation, a strong country, an equal, republic and civilized society.

It can be seen that the spirit of religious freedom and unity, of creating an environment of equality among religions of the Party and the State of Vietnam in the recent years have considerably contributed to the revival and development of religions. Religious diversity in Vietnam nowadays is established on the basis of the spirit of tolerance and equality between religions and before the laws. The Party and the State always respect and ensure the healthy development of all religions.

\section{THE CHARACTERISTICS OF RELIGIOUS PLURALISM IN VIETNAM}

\section{Religious pluralism}

The concept of religious pluralism usually finds expression in the actual diversity of religions (religious diversity) existing and the adaptive capacity of the_various religions. Broadly, religious diversity reflects the idea of the members of different religions who can practice and develop their traditional beliefs among those who oppose it in a normal environment. Generally, pluralism is an attitude regarding the diversity of systems co-existing in society. This concept is often used in many different ways in many different issues. Many researchers believe that the theory of pluralism is said to begin with religion and is associated with religion (Mattia Ricardi, 2016)_This means that the idea of pluralism is closely connected to religion. In fact during th ancient times prayed to many gods all at the same time. There is the belief in many gods and many associations of god with the objects of nature - the tree, stone, sky, thunder or with animals like cow, eagle, snake and dragon and this points to the belief in many gods This belief in nay gods to a pluralistic religious belief.

Diana L. Eck (2006) has claimed that cultural and religious diversity is the basic characteristic of every region worldwide. Grounding herself on such thesis, she developed the concept of "pluralism." That is not the sheer fact of plurality or diversity alone, but an active engagement with that diversity. One can be an observer of diversity. So, real pluralism requires participation and engagement. She also emphasized the characteristics of religious tolerance in pluralistic environments. According to Eck $(2006,1)$ "pluralism is more than the mere tolerance of differences; it requires some knowledge of our differences. There is no question that tolerance is i mportant, but tolerance by itself may be a deceptive virtue. Sometimes 


\section{NGUYEN THI MINH NGOC}

an attitude of tolerance may stand in the way of engagement. Tolerance does not require people to know anything at all about one another." Most importantly, pluralism is not simply relativism, but makes room for real and different religious commitments. Eck $(2006,2)$ further said that "pluralism does not require relinquishing the distinctiveness of one's own tradition of faith to reach the "lowest common denominator." In the public square of a pluralist society commitments are not left at the door. Rather, pluralism invites people of every faith or of none to be themselves, with all their particularities, and yet to be engaged in creating a civil society, through the critical and self-critical encounter with one another. Pluralism is a process of creating a society by acknowledging, rather than hiding, our deepest differences. So, pluralism relies on communication. The language of diversity is the language of communication and encounter, give and take, criticism and self-criticism. Pluralism is related to on-table-commitments with an individual's commitments.

Some researchers (Eck 2006; Massanari 1998)) opine that pluralism is not a new phenomenon and it is not a combination of the traditional system of values, the life style, and the different lines of thinking, either. Pluralism is not the sum of that system. At the beginning, pluralism is an attempt to adapt to the survival of a "non-religions" society that was discovered in the heart of Catholic Christian society in the middle of the fourth century. The Christian Church's acceptance and compromise with the non--Christian culture (as opposed to the cultural Christian-Catholic) was the starting point of pluralism. Eventually after a number of centuries, the principle of "uniformity in difference" permeated European societies (Nguyen Thi Minh Ngoc 2016, 12).

Religious pluralism is the acceptance of one religion towards others by the law or through individuals' freedom to choose his/her religion. Many believers hold that pluralism of religion should encourage cooperation rather than competition and that, changes in theology are necessary to overcome the differences between religions as well as between different branches or sects within the same religion.

The concept of religious pluralism is not new, but only in the modern society has it been raised systematically. Religious pluralism is a universal phenomenon and a common characteristic of religions in the world. Religious pluralism is among the most important issues of religion worldwide in the peculiar conditions of the modern society. The theory of religious pluralism introduced by the philosophertheologist John Hick (1922-2012) is highly appreciated. Based on this theory, researchers can study the issue of religious pluralism in particular religions and in particular geographical areas (countries, nations, tribes). John Hick (2005) himself also continued to implement his own theory with studies of religious pluralism in various aspects. Chinese researchers Wong and Wai Yip (Wong Wai Yip 2012) have applied Hick's religious pluralism theory to recognize religious pluralism in Chinese folk religions. The study of religious pluralism in the countries and religions themselves complements Hick's theory. Hick (2005) himself continued to supplement his theory of religious pluralism with empirical studies of religious pluralism in many different aspects. Recently, he delivered a speech on religious pluralism in the Muslim world. 


\section{Vietnamese Religious Diversity and the History of Vietnam}

Vietnam is a multi-ethnic and multi--religion country. Since the ancient times, the religious life of the Vietnamese people has been extremely abundant. Practices of Vietnamese worshipping have demonstrated the essence of native polytheism. Animism and the belief and worship of nature are common kinds of ancient beliefs; but the same natural phenomenon is manifested in many different forms of worship. For example, the worship of agriculture's Gods varies from one ethnic community to another. These activities are common among the Vietnamese ethnic communities and each of them has its own distinct characteristics.

Buddhism came to Vietnam and was integrated into the local agriculture beliefs to form the Four Dharma Buddha (Tứ Pháp Phật) system. It is also the sign of the combination of traditional indigenous beliefs with religions. Vietnamese people worship their respective village's God. But mixed in with that is imprint of the traditions of worshiping the Gods of Nature manifested in such festival activities as "tùng dí," "catch scouts in jars" (bắt trạch trong chum), and "turn of the light" (tắt đèn).

Vietnamese religious diversity also clearly reflects the process of national development. Every period has left its specific hallmark on religion and the latter are integrated with the former. Matriarchy promoted the role of women and made up the peculiar system of goddess worship. Goddess worshiping (tục thờnữ thần) is an ancient religious tradition that is rich in genres and is present throughout the country, each with its own characteristics.

The major historical events of the world and Vietnam have led to the entry of many ethnic groups and religions such as Buddhism, Taoism, Christian, Protestant, and Islam into Vietnam during the long history of development. Thanks to the current innovation perspective and awareness of the Party and the State on religions, accompanied by a change of religious policy, the Vietnam religions find themselves in more favorable conditions for development. Currently, there are 13 religions and 40 religious organizations that are officially recognized by the State. According to the data from the 2009 Census of Population and Housing in Vietnam, 14,718,971 people throughout Vietnam have confirmed membership in a certain religion.

\section{Pluralism is a universal phenomenon for Vietnamese religions today}

Nguyen Thi Minh Ngoc (2016,63-132) had summarized the characteristic of Vietnamese religious pluralism. According to her, religious pluralism is one of the basic characteristics and is a universal phenomenon of religions in Vietnam. Looking back at the historical development of religion, we found out that Vietnamese religions are characterized with high amalgams. The amalgam is the basic factor to make pluralism. The reality of amalgam refers to the religion mix of two or more belief systems together in the same belief system. These are rules that always exist when many religions coexist in the same culture. We can say that Vietnam is one of the typical countries of amalgam religion. The elements of history, geography, culture and ethnicity have enabled the country to become a multi-religions country. 


\section{NGUYEN THI MINH NGOC}

On the other hand, religious amalgams can also be seen from the perspective of religion itself. In Vietnam, they tend to avoid conflicts with indigenous beliefs by mixing up with them intentionally to guarantee their survival and development. Therefore, in Vietnam, religious amalgams are not just a phenomenon occurring during acculturation and cultural exchanges but also an effective solution for the integration of religions so as to promote their influence. When coming to Vietnam, all religions initially had the desire to eliminate indigenous religions, especially the traditional ones, but none have managed to do that until this day. So if a religion wants to survive and grow, it must find ways to localize so as to fit into the polytheistic and/or pantheistic consciousness of the local agricultural population. Additionally, the Vietnamese people's peaceful tolerance towards various religious systems has created a symbiosis and coexistence of various faiths. This is an important condition for the formation of the phenomenon of religious amalgams in Vietnam. The concept of religious amalgams has nothing to do with the predominance of indigenous belief systems or any religion at all; this phenomenon is merely an effective solution to these religions which exist together in harmony. The phenomenon of religious amalgams is most clearly seen in Buddhism. So far, Buddhism is a religion that has "localized" the most successfully. The Buddhist amalgam is of a long tradition and can be seen clearly through the triple-religion amalgam. The triple religion model is a popular mode of Vietnamese Mahayana Buddhism. The model itself is not originally Vietnamese because it could be traced to the Song dynasty in China. It entered Vietnam in the second century and, since then, has been preserved to the present day. It is also a typical hallmark of the nature of religious pluralism of Vietnamese Buddhism.

Moreover, there is an amalgam between Buddhism and the traditional religion of mother worship. The combination took shape in the 15 th century with the presence of Lieu Hanh -mother worship (Mau) in the pagoda. Today, the practice of mother worship is a common feature in Mahayana pagodas, and paying homage to her is a significant ritual among the pagoda goers. Sometimes, they even consider Mau more respectable than the Buddha. In fact, over the years, the position of mother worship in the temple has tended to become more and more significant. Almost all Mahayana temples (except for Truc Lam) have separate worship space for mother worship, or at least a separate altar in the main hall. This is one of the characteristics of Vietnamese Buddhism in the market economy circumstance. The pagoda goers perceive that mother (Mau) is close to them, while the Buddha is far off. Worshiping the Buddha means wishing for liberation in the next life, while worshipping mother (Mau) is for the present daily mundane life. For the time being, the elements of the daily mundane life are the the biggest concern of the people, so, we can easily understand the motives of the pagoda goers' belief and behavior.

\section{Vietnam's religious pluralism marked by migration flows}

Vietnamese religions have been strongly influenced as well by the migration process. Migration is a common historical reality, not a new phenomenon and leads to the transformation of religious structures. Migration creates religious pluralism and has 
religious, geopolitical and cultural impacts. Migration has flown from the north and brought to Vietnam the religions Taoism, Buddhism and Confucianism, along with the perception of triple religion. At the same time, Buddhism also came to Vietnam together with Indian traders and got associated with Vietnam indigenous religion which evolved into the Four Dharma system.

Migration, one of the elements that make religion spread from one region to another, is the primary factor that makes up the cultural and geopolitical identity of the Vietnamese religions. Many religious exoduses were associated with socio-political contexts, an example of which is the exodus of Catholics into Dongnai. Later, a large exodus of the Catholics into the South took place in the period from 1954 to1959. As a result of the Genèva agreement, northern Catholics immigrated into the South and formed a new community with its own identity. The Catholic communities often followed the structural model which characterized their village communities in the North. The migration wave posed many challenges to the Church in the south as it had to assimilate a group even larger than itself. At the time of the Geneva Agreement (1954), there were about 1.9 million Catholics in Vietnam, of whom only $520,000(27.4 \%)$ who lived in two southern provinces belonged to the church in Saigon and Hue. However, by the end of the migration wave from the North, nearly 1.7 million Catholics (61.6\% of the total Catholic population of Vietnam) settled down in these areas (Hansen, 2010). The migrants from the North to the South included not only Catholics but also Buddhists and Protestants. Among the three groups, there were 676,348 Catholics (76.3\% of the total number of immigrants), 209, 132 Buddhists (23.5\%), and 1,041 Protestants $(0.2 \%)$ (Hansen, 2010). It can be said that this exodus helped to create religious diversity for the Southern area of Vietnam.

The migration of Chinese ethnic groups into the Vietnam regions also contributed to the formation of religious diversity in Vietnam. The Chinese community had been present in Vietnam since the very early stage of history. They migrated to Vietnam from the south of China and brought their religion with them. Many elements of Chinese religions were accepted by the Vietnamese people, including ancestor worship, resource worship, and kitchen God worship. Chinese traditional religions like Thien Hau worship and Guan Gong worship have been accepted by many ethnic communities, especially the Kinh ethnic community.

Migration at the present time has brought about local religious transformation. The most typical is the migration in the Highlands, a region with a high proportion of immigrants. Highland immigrants belong to various religions and have caused changes to Highlands's religious structure. There are Catholics, Protestants, Buddhists, Cao Dai and followers of a small number of other religions. Currently, according to Government Religious Affair (2008) which surveyed the new religious movements in our country today, nearly $40 \%$ of the Central Highlands population belongs to some religion, the biggest numbers is that of the Catholics, next come the Buddhists, Protestants, and finally the Cao Dai, Baha'i and others. The questions and also the challenges are the destruction of the traditional social structure of the ethnic-religious community caused by religious elements brought in by the immigrants. This community structure has strongly influenced the social life in the Highland. Religions, especially Catholicism 
and Protestantism, have contributed significantly to change the local people's perception and make them abandon the bad traditional practices, improve their scientific and technical knowledge of production, as well as their knowledge of food safety, and health care. However, the religions also have brought about conflict between different religious communities. Initially, the conflicts appeared as a conflict of values, culture, but then turned into real social conflicts. This means that religious issues have become a cause of political instability and social unrest in the Highlands today.

The rural-urban migration wave together with the formation of industrial zones and export processing zones constitutes yet another factor leading to religious pluralism. In fact, migrants often bring their religious traditions to their new residences. However, the rural migrants to the urban areas do not have strong impact on religious diversity. In contrast, the formation of industrial zones today is one of the factors that make up the religious diversity. Previously, the major religions such as Buddhism, Catholicism and Protestantism were brought to Vietnam by foreign merchants who came to Vietnam. Nowadays many religions and religious traditions have been brought to Vietnam by foreign investors and have formed new religious sects in the industrial areas where these investers live and work. Vietnamese Protestants are currently affected by Korean Protestant mainly because of Korean investors who come to Vietnam. While in Vietnam, they maintain their traditional religious routines. In many industrial areas, due to the influence of foreign owners, many Vietnamese workers have gradually become followers of the religion of the business owners. In this way, the religions that the investors follow have gradually spread in the Vietnam society. Some new religious sects have come into being and flourished in this way.

\section{Religious Pluralism and the Flourishing Development of New Religious Movements in Vietnam}

The emergence of new religious movements has been a common phenomenon of world religions since the late 19 th century and early 20 th century. This is one of the central issues of world religions for the 20th century. The growth of new religious movements more or less affected religious life in in general. Basically, the new religions in Vietnam can be divided into 5 categories: first, new religious movements brought in from other countries; second, new religious movements that are of great similarities to the great religions in the world like Buddhism, Catholicism, Protestantism; third, new religious movements that bear resemblance with the traditional religions; fourth, new religious movements with extreme behavior in practice; and fifth, unidentified new religious movements.

The followers of new religious movements themselves are under remarkable pressure from their respective families and the society. The society does not acknowledge their religious needs, and many of them witness strong objections from their own families. The fact that numerous individuals have become followers of the new religious movements despite the social pressure showed that the movements have addressed the adherents' spiritual needs. The researcher believes that the followers of the new religiousphenomenon mainly belonging to the "vulnerable" group in the society, most of 
them are women with difficult lives, precisely got converted because of the rapid changes and the impact of various aspects of real life with which they have difficulty coping. They are the poor people in both rural and urban areas, retired officials or civil servants. Most of them used to be primarily followers of some religions and traditional beliefs, but they got disappointed with them and thereby sought new religious movements to satisfy a personal religious need that the traditional religions failed to satisfy. This take place in a society where the individual needs are ranked higher than before, and selfindulgence is becomin more and more are common attitude and behaviour.

New religious movements, both in the world and in Vietnam, share the mark of valuing individuality in its harmonious relation with the society. At times labelled as "messianic," the new religious movements focus on the human individual demands, paying attention to the secular world rather than the non-secular one (Government Religious Affair, 2008, 16). The traditional religions set the human world after death as their ultimate goal, thus the appreciation of the values of enlightenment, liberation, for a world of "heaven" in "extreme bliss." However, in modern society, the theoretical basis of traditional religions is to some extent no more appropriate. This perhaps is the reason behind the appearance of the new religious movements - they care for the need of each individual in a society that is experiencing swift changes. The appreciation of individual spiritual needs of the new religious movements are seen in their organizational structure and doctrinal base.

Overall, the new religious movements exist in small groups of a few dozen, a few hundred, or a few tens of thousands of followers at most. The followers of the movements hope to overcome the feeling of insecurity in their daily lives, with many of them belonging before to the traditional religions. Existing in small groups, the new religious movements have simple organization, flexible mode of operation, and easy performable ritual practices. These features suit well the needs of groups of people with low education and low income.

The appearance of new religious movements is an inevitable phenomenon. In the context of religious pluralism, it is impossible not to acknowledge their existence. These new religious movements bring disturbance to both religious life and social life. The formation and growth of the new religious movements have added new aspects to people's religious life. They are contributing to the abundant diversity of the already diversified and enriched Vietnamese religious panorama.

\section{RELIGIOUS BELIEFS IN TERMS OF RELIGIOUS PLURALISM IN VIETNAM TODAY}

Since 1990, the changes in religious policy have contributied to more favourable conditions for the development of religions, and there has been more attention paid to religious studies. For that reason, many surveys had been conducted. In this paper the author uses data from four surveys of religions including two nationwide surveys of religion. The first one was from 1992 to 1994 and the second one was from 1995 to $1998 .{ }^{2}$ These were the first religious surveys conducted on national scale by the government 
which was fortunate to have a staff of researchers who were really experienced in carrying out sociological surveys. The questionnaire adopted a Western model done in some Western countries. The major purpose of the survey was to find out facts about the people's religious beliefs and their participation in religious activities in Vietnam. The biggest limitation of the survey was the failure to distinguish the Catholics from the Protestants whereas a distinction was made between the Buddhists and Christians. The second limitation pertains to the data collected from the survey carried out in five Central Highlands provinces by the Institute of Religious Studies in 2013 in the framework of the State-level project entitled, "The role of religion in the sustainable development of the Central Highlands." A quantitative questionnaire was used to collect data about the three religions: Buddhism, Catholicism and Protestantism. Some questions in the qquestionnaires were the same ones used in the previous surveys so as to ease the comparison and contrast of the data. A total of 1178 people were asked broken down into 396 Buddhists (33.6\%); 399 Catholics (33.9\%); and 383 Protestants (32.5\%). The third research was a survey on the Catholics and Buddhists in Hanoi and Ninh Binh in 2014 , carried out by the author. Its title was "The role of religion for the construction of social trust." The total number of informants was 651 , with 343 Buddhist respondents $(52.7 \%)$ and 308 Catholic respondents (47.3\%). The researchers hoped that the overall surveys done by the Institute of Religious Studies would bring about an overall view of the peoples' religious beliefs in Vietnam in the early stage of the renewal cause and the two later surveys ( carried out in 2013 and 2014 with the same questionnaire) would provide an insight into religious believers in Vietnam today.

\section{Religious beliefs of religious adherents in Vietnam today}

Religious belief is among the key elements that constitutes a religion. According to Dang Nghiem Van (2001), every religion has a system of beliefs that is formed with emotions through religious activities in various forms and is governed by some surealist (or transcendental) content. This system of beliefs aims to gather the followers into a social community whose members efficiently support each other making religious followers believe, carry out religious practices, make them put their faith in the things that non--followers would consider absurd and become faithful followers. Religious beliefs should be distinguished from secular beliefs. To speak of religion means to speak of sacred elements related to the invisible world; the sacred power can affect human beings. Thus, religious belief is the belief in the supernatural, in a psychic power that is unevely distributetd to members of a religious community. Religious belief is a metaphysical one, which does not base on rational reasoning and experimentation. Religious belief is mostly felt, based on traditional experience or firmly asserted after industrious cultivation. Religious belief does not require proof. It is the belief in the eternal, the absolute. The content of religious belief depends on the teachings and values of each religion; therefore, there are differences in religious belief of different adherents of the same religion, as well as differences among adherents of different religions. The differences between various religious beliefs pose the issue of religious pluralism whose essence is religious tolerance and religious dialogue. 
Religious belief is a factor that is difficult to measure. To measure religious belief, sociologists use indicators of religious behavior. Through the act of participating in religious activities such as participating in attendance at religious institutions, participating in religious education activities, and the level of understanding ritual religious teachings researchers can assess an individual's level of religious belief.

According to many researchers, since the beginning of Innovation (1986) religions in Vietnam have revived after a long sleep. The resurgence of religion in Vietnam is believed to have close ties with social and economic transformations, especially in the restructuring of the economy from the centralized bureaucratic economy into the marketoriented socialist one. Economic changes led to drastic changes of social life. The direct impact of social and economic life on the changing perception of religion can be noticed through specific changes in religious policy of the Party and the State to create favorable conditions for the revival and development of religion.

Besides, the fundamentals that determine the recovery and the development of Vietnam's religions are precisely religious needs. According to Dang Nghiem Van (2001), ever since the time human beings learnt to organize their society, they have had religious needs. Religion was created by the people who felt the same need for religion, and that means religious needs are the needs of the masses. Religious needs reflect each individual's needs of divine, supernatural forces to support the development of the community as well as to protect individuals against the uncertainties and risks in their lives. In terms of social change, after so many innovations, some Vietnamese found life precarious and sought spiritual support in religions. The recovery and development of religions in Vietnam after the innovation truly meet the needs of these people. The main religious needs have contributed to shaping the development of Vietnamese religions.

Religious needs and the timely response to the needs of the Vietnamese religions are very clearly seen through indicators of religious belief. The first indicator is attendance at religious institutions. Religions in many countries in the world witness a decline of churchgoing to attend regular worship, while churchgoing in Vietnam gets a high percentage. The results of the first survey with questions about the regularity of church going of Christian believers (including Sundays and holiday's feasts) got 56.4\% positive answer in Hanoi and $90.32 \%$ positive answer in Ho Chi Minh City. The survey also showed similar results for the attendance in the eucharis and confession activities.

For religion-less people, their religious consciousness or religious needs are also shown through their ancestor worshiping. The majority of these people regularly worship their ancestors. For the results of our survey see Table 1 on the next page.

Results of the second survey of the Institute of Religious Studies also show that religious beliefs in Vietnam are very strong. The rates of feast participations are very high with $91.0 \%$ frequently do it. People who go to church every day accounts for $24.1 \%$ and occasionally, $59.8 \%$ while people who go to church every Sunday is $32.1 \%$ and occasionally, $66.0 \%$. People who pray at home regularly make up $26.8 \%$ and occasionally, $69.0 \%$. These average proportions are differences between various areas.

The religious beliefs of Christians are also reflected in their expressed faith in the Lord and adherence to the basics of Christian doctrine. The survey results show that 
Table 1: Frequency of ancestor worship participation of religion-less people

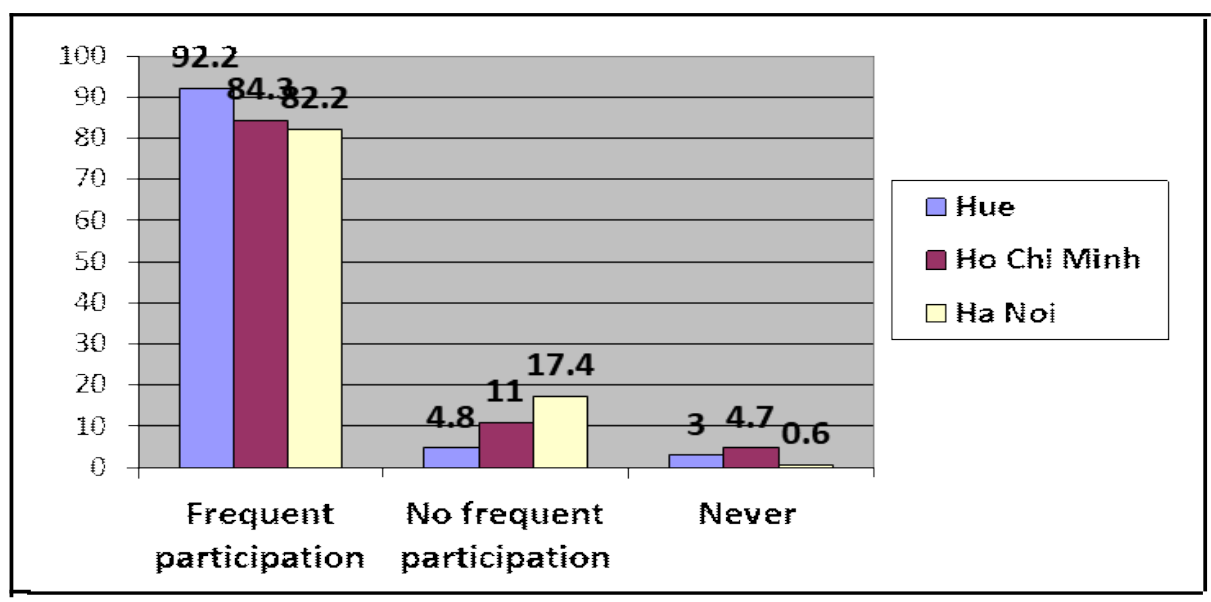

$98 \%$ of them believe the presence of God; $93.5 \%$ believe that humans were created by God; $90.4 \%$ believe in the Sin; $83.5 \%$ believe in doomsday; $91.5 \%$ believe in the Holy Communion with God; $79.8 \%$ believe on the claimed apparition of the Virgin Mary.

For Buddhists, the devotees to the temple regularly going accounted for $14.1 \%$ of the respondents while $31.5 \%$ for those occasionally going. Religious beliefs of the Buddhists are not as deep as that of the Christians. This is shown in the number of the Buddhists who worship the Buddha or doubt the power of Buddhist mystics. Only $18.25 \%$ of the Buddhist respondents based in Hanoi, $78.9 \%$ in Hue and $65.4 \%$ in Ho Chi Minh City worship the Buddha; $49.64 \%$ of the Buddhist respondents in Hanoi, $80.3 \%$ in Hue and $72.9 \%$ in Ho Chi Minh City believe in the Buddha. These data reveal that the level of belief in Buddha is quite different from one area to another. The Buddhists in Hue appear to have the strongest belief.

The 2013 and 2014 surveys of the Institute of Religious Studies in the five provinces of the Central Highlands, Hanoi and Ninh Binh also show the deep religious belief of religious believers today. The results are as follows: Highland Catholics have deep religious belief and proper awareness about the Catholic doctrine. Almost all believers believe in the existence of heaven $(99,0 \%)$, the existence of hell $(98,0 \%)$, purgatory (94,5\%), man be borne by God, the Eucharist (98.7\%), allowed himself to holy communion with God (100\%), the existence of devil (94.0\%), $\sin (97.2 \%)$, doomsday, the Lord comes again $(93.5 \%)$, life in heaven $(97.7 \%)$, apparitions $(97.5 \%)$, miracles $(96.2 \%)$, and fate $(58.1 \%)$. There are no significant differences between the beliefs of men and those of women on the Catholic doctrines, except the belief in fate. This reflects the nature of the woman since they do not have good self-confidence, and, furthermore, do not believe that they are the ones who decide their own destiny.

Like the Catholics in the highlands, Hanoi and Ninh Binh Catholics have strong belief in the existence of such notions and things like heaven, hell, purgatory, the 
Eucharist, devil, sin, doomsday, life in heaven, apparitions, miracles, and fate. They also strongly believe that man was created by God, that the Lord will come again, to holy communion with God. The results are as follow:

Table 2: Belief in dogmas of the Catholics in Hanoi and Ninh Binh

\begin{tabular}{|l|c|c|c|c|}
\hline \multirow{2}{*}{ The dogmas } & \multicolumn{2}{|c|}{ Hanoi } & \multicolumn{2}{c|}{ Ninh Binh } \\
\cline { 2 - 5 } & Men (\%) & Women (\%) & Men (\%) & Women (\%) \\
\hline The existence of heaven & 91.9 & 98.8 & 96.1 & 95.3 \\
\hline The existence of hell & 91.9 & 95.2 & 92.2 & 94.4 \\
\hline The existence of purgatory & 74.2 & 94.0 & 90.2 & 92.5 \\
\hline God created Man & 91.9 & 98.8 & 92.2 & 94.4 \\
\hline $\begin{array}{l}\text { Allowed himself to holy communion } \\
\text { with God }\end{array}$ & 90.3 & 100 & 96.1 & 98.1 \\
\hline The existence of devil & & & & \\
\hline Sin & 93.5 & 95.2 & 88.2 & 91.6 \\
\hline Doomsday, the Lord comes again & 75.8 & 96.4 & 92.2 & 94.3 \\
\hline Life in heaven & 82.3 & 85.7 & 90.2 & 91.6 \\
\hline Apparitions & 88.7 & 94.0 & 94.1 & 94.4 \\
\hline Miracles & 85.5 & 92.9 & 68.6 & 86.8 \\
\hline Fate & 48.4 & 66.7 & 76.5 & 90.7 \\
\hline \hline
\end{tabular}

Catholics appear to be devout believers. Up to $92.2 \%$ of the people in the Highlands; $82.6 \%$ in Hanoi and $89,9 \%$ in Ninh Binh regularly attend religious teachings. This life style has a strong impact on the children of the Catholic families with $92.7 \%$ of Highlands children, $73.0 \%$ of Hanoi children and $86.7 \%$ of Ninh Binh children participate in all the catechism classes. Thus, there were differences in catechism attendance among the three places. In particular, Hanoi is the place where believers face more pressure of life than other localities, and people tend to spend less time for religious activities. The Catholics' devoutness is also seen in the high proportion of church going respondents: $97.7 \%$ of Highland; $86.6 \%$ of Hanoi and $89.9 \%$ of Ninh Binh Catholics regularly do it. The main reason for their going to church is their faith expressed by $96.0 \%$ of Highland respondents; $93.9 \%$ of Hanoi and $93.7 \%$ of Ninh Binh. Praying with the Bible is important to the Catholics as revealed in the breakdown of percentages: $86.5 \%$ of Highland; $65.5 \%$ of Hanoi and $86.3 \%$ of Ninh Binh say their prayer at home every day.

Highland Protestants have profound belief in the basic tenets of Protestantism: 99.0\% believe God is the Almighty who created the universe and humankind; $97.1 \%$ believe in Heaven and Hell; $83.3 \%$ believe the devils are real and they exist in daily life; $93.0 \%$ believe the Lord will be coming and there are signs indicating the date is approaching; 64.85 believe in miracles as prophecy that the phenomenon of speaking in tongues do happen in daily life; $95.0 \%$ believe the Bible was inspired by God and is 
infallible. Most Highlands Protestants participate in every religious activity. However, there is one thing that they have not done properly: contributing $10 \%$ of their income to the church.

For the Buddhists, their deep belief is seen through their purpose for following their religion. The greatest desire to become a Buddhist of the people in Highlands, Hanoi and Ninh Binh Buddhists is to improve themselves (76.5\% of Highland; $81.6 \%$ of Hanoi and $81.6 \%$ of Ninh Binh). This shows that the moral values of Buddhism have profoundly and positively impacted the social life. Only a few Highland people choose to become a Buddhist for such pragmatic purposes like making a fortune, while many people of Hanoi (71.4\%) and Ninh Binh (65.4\%) become a Buddhist for that reason. It can be seen that the social and economic characteristics have their own effects on the religious purpose of the Buddhists. In places where daily life issues are the top concerns of the people, or in the economic centers like Hanoi where people face with the fear of failing to earn enough money to live on, the Buddhists wish that the Buddha would help them solve the problems of everyday life. They wanted to find their fortune in religions.

Generally, the Highlands and Ninh Binh Buddhists have good knowledge of the Buddha. Most Buddhists believe that the Buddha was enlightened (82.3\% of Highland and $72.3 \%$ of Ninh Binh), who had the power to relieve suffering and distress (72.5\% of Highland and $73.0 \%$ of Ninh Binh). But, the Hanoi Buddhists do not have a proper understanding of the Buddha. Only $58.7 \%$ said that Buddha was enlightened and $23.8 \%$ said that Buddha was someone who could relieve people's suffering and distress, whereas $90.2 \%$ said that the Buddha was a saint. Attending the teaching sessions of the Buddhist doctrine is the main activity of the Buddhists, and this helps to create their strong, profound belief as well as their right perception of Buddhism. $71.7 \%$ of the Buddhists in the Highlands regularly participate in these activities. In contrast, the ratio of Hanoi and Ninh Binh Buddhists who attend this activity are low $(29.7 \%$ of Hanoi and $28.9 \%$ of Ninh Binh).

The Bible is of great interest to Highland Buddhists. Up to $55.8 \%$ of the Highland Buddhists do their religious chanting daily. Differing from those in the Highland, far fewer Hanoi and Ninh Binh Buddhists do their daily chanting. Only $24.4 \%$ of Ninh Binh and $9.7 \%$ of Ha Noi do it daily.

The Highland Buddhists have profound religious belief, which is seen through their active participation in ritual activities. Up to $82.8 \%$ of the Buddhists regularly go to pagodas. The percentages of Hanoi and Ninh Binh Buddhists who are regular pagoda goers are lower than that of the Buddhists in the Highland as follows: (see Table 3 on the next page)

So there are differences in religious belief as seen through people's participation in religious practices in the research sites. Highland believers appear to have the most frequent participation in religious practices, followed by the Ninh Binh and Hanoi believers respectively. Hanoi, which is the capital and the economic-political-cultural center of the country, seems to have the weakest of religious beliefs seen through their least requent participation in religious practices. 
Table 3: Frequency of the pagoda-going Buddhists of Hanoi and Ninh Binh

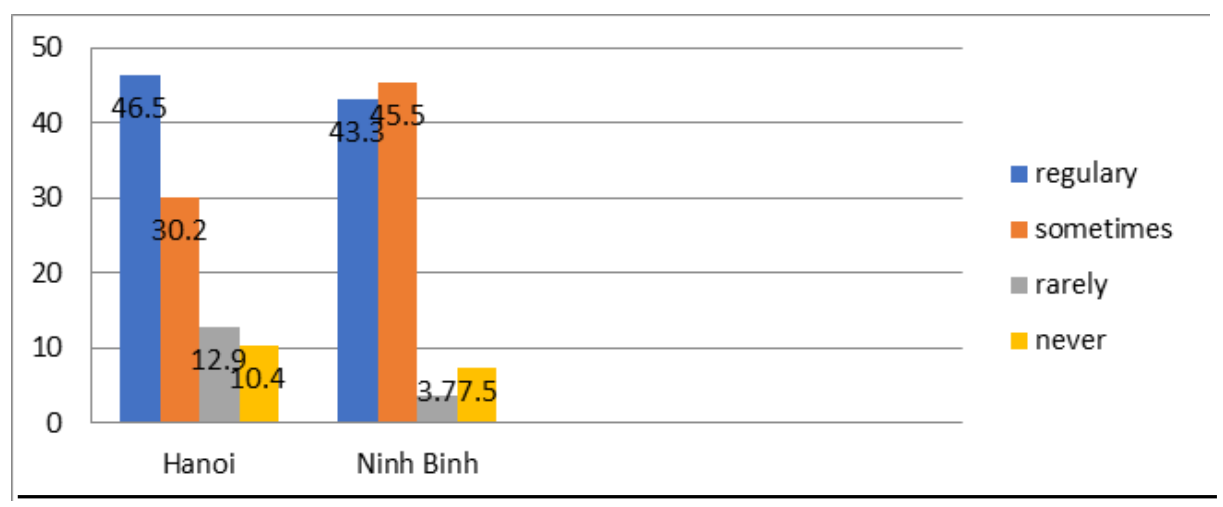

These figures provide us an over view of religious belief in Vietnam today. It is also an indication of distinct characteristics of religious life in Vietnam. Currently, some countries in the world are witnessing a decrease in churchgoing practices, side by side with an increase in personal religion preference. The Vietnamese religions still retain their traditional characteristics. Despite certain signs that reflect the process of integration and changes in the conditions of modern society, religious ceremonies in Vietnam still adhere to their traditional form. If in the US, we can easily attend a Catholic Church service with Pop or Rock music, in Vietnam, that such kind of music is not possible up until this point. The typical and traditional values surely make up the foundation for the devout and deep belief of believers in Vietnam today.

\section{Religious pluralism in Vietnam from the perspective of religious belief}

Religious pluralism can be viewed from many different perspectives but we approach this from the perspective of religious belief, in which pluralism is seen in the mixture of religious beliefs of believers. The pluralism of religious beliefs of Christianity is reflected in the acceptance of ancestor worship. Polytheistic/pantheistic religious consciousness is one of the characteristics of Vietnamese religions today. To survive and grow, the Catholics have to pay attention to this feature. In recent years, in fact, the Vietnamese Catholic Church has shown respect for other religions, including traditional ones. In fact, the Catholics nowadays are allowed to openly worship their ancestors, national and local heroes. The survey results of the Institute of Religious Studies at the Highlands, Hanoi and Ninh Binh in 2013, 2014 reflect this situation.

The results show that the majority of Highlands Catholics now worship their ancestors. Up to $82.2 \%$ of them have a permanent altar at home and $78.7 \%$ All Souls Day. Hanoi and Ninh Binh Catholics also express profound faith for ancestor worship. Up to $63.8 \%$ of Hanoi and $56.6 \%$ of Ninh Binh Catholics have permanent altars at home. 71, $1 \%$ of Hanoi and 5,2\% of Ninh Binh Catholics give feasts the deads'day. Thus, there are 
differences in ancestor worship between study sites, which present different levels of religious pluralism between regions.

Table 4: Forms of ancestor worship of the Catholics in Hanoi, Ninh Binh and Highland

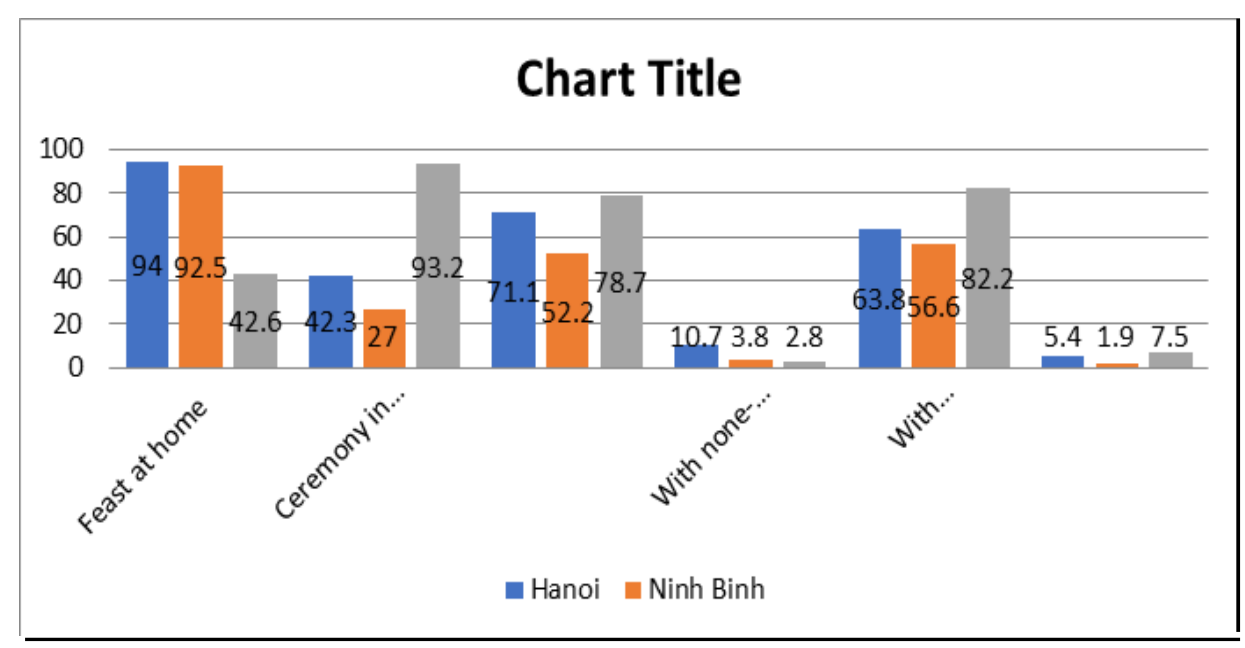

These kinds of activities are not accepted by the universal Catholic Church. In the context of Vietnam, however, ancestor worship which is an expression of the traditional religion has been accepted by the Catholic missionary church in Vietnam which points to the church's missionary approach which recognizes the integration of indigenous culture and religion. A bishops' conference on held on November 14, 1974 in Nha Trang issued a resolution on the issue of ancestral.

Catholic participation in festivals of other religions is also an indicator of religious pluralism among the Catholics. The survey results show the high percentages of Catholics attending non- Christian festivals.

Table 5: Percentage of Catholics attending non-Christian festivals

\begin{tabular}{|l|c|c|c|}
\hline \multicolumn{1}{|c|}{ Attendance of non-Catholic festivals } & Highland (\%) & Hanoi (\%) & Ninh Binh (\%) \\
\hline Traditional community festivals & 43.1 & 78.8 & 56.8 \\
\hline $\begin{array}{l}\text { Political festivals organized by the local } \\
\text { government }\end{array}$ & 42.9 & 24.0 & 56.8 \\
\hline Other religious festivals & 41.6 & 28.1 & 25.9 \\
\hline
\end{tabular}

The results also show that the proportion of Christians who attend the ceremonies organized by other religious bodies of Hanoi and Ninh Binh are lower than that of the Highlands. This reveals that, in this respect, Catholic pluralism is stronger in the Highlands than in Hanoi and Ninh Binh. 
In the environment of religious pluralism, the model of a multi-religious family has been brought to the front. Survey results showed that $73.2 \%$ of Highland Christians, $71,8 \%$ of Hanoi Christians and $63,5 \%$ of Ninh Binh Christians accept marriages between Catholics and non-Catholics. Remarkably, up to $48.4 \%$ of Highland respondents, $27,7 \%$ of Hanoi and 77,4\% of Ninh Binh Catholics hold that if one marries a non-Catholic he can still keep his own religion. Thus, concerning marriage, the Ninh Binh Catholics expressed tolerance for other religions. However, this point of view has not been acknowledged and appreciated by religious leaders. Catholic dignitaries still require non-Catholics to become Catholic if they want their wedding ceremony to be held in the church. This creates a considerable pressure on those who want to marry Catholics and at the same time to continue with their own religion. A case in point: a Vietnamese lady, Ms. H, 35 years old, from Tuyen Quang but now living in Hanoi, got married to a Catholic man. She said that before the marriage, she took a pre-marriage course at Thai Ha Church, and had the consent of her husband to keep her religion after their marriage that is to worship (ancestors) in accordance with the customs of her family. However, after the birth of her children, although she did not want to convert to her husband's religion, the religious leaders at her husband' homeland (Hanam province) put pressure on her husband's parents to press her to do it. They declared that they would not allow her husband's parents to have their funeral held at the church, and in that way, according to the Catholic perception, they will not go to heaven. For that reason, her husband's parents strongly pressured Ms. H to convert into Catholicism, or at least to make their son Christian. Failing to put up with the family pressure, Ms. H had to let her child take baptism. From that time on, she would often cry and felt like she had lost a child. This is the fundamental difference between the multi-religious family model in Vietnam and that in the West. In the US, the multi-religious family model is one of the basic family models. In that family, members can keep their own religious beliefs and practices. Everyone in the family respect the religious beliefs of others. We believe that, in the future, with strong international integration, this type of multi-religious family model will be gradually accepted in Vietnam.

Religious pluralism is not just a challenge but also a characteristic of Buddhism in Vietnam. Triple-religion is among the basic models of Vietnamese Buddhism, which features Buddhism's acceptance and respect for numerous religious beliefs. In the Buddhist pagoda, symbols of other religions (namely Confucianism, Taoism and Mother worship - a kind of Vietnamese traditional religion) can be found simultaneously. In contrast, in Mother Worship, one can notice signs of Buddhism. The official presence of various religious sects on the shrines evinces religious pluralism beliefs of the Vietnamese Buddhists and Vietnamese people. Religious pluralism is also clearly reflected in religious consciousness of Buddhists. A Buddhists doing a small business in Hanoi told us that she has converted herself into a Buddhist for five years, and every month whenever it is full moon and new moon, she would go to the pagoda, and would participate in most of the activities organized by the temples. Besides, she also often goes to Mass at the temples like Tay Ho temple and Ung Thien temple. She believes in the Buddha and understands that the Buddha's teaching makes people improve themselves. However, 
she also claims that his teaching is not of much help in her business. She has found out that she appears to get more help from the invisible world whenever, according to her, she would pray for fortune at the temples. Therefore, being a Buddhist, she still goes to temples to say her prayerrs. There are many Vietnamese people going the temple to pray and the first sentence they said is Nam Mo A Di Da Phat is a prayer that expresses their respect before the Buddha. It is wrong to say that at the temples where the Buddha is, he is not worshipped. This behavior shows the existence of religious pluralism in the minds of the Vietnamese people. They go to pagodas or temples without paying attention to the basic principles of their worshipping object. They pray any objects that meet their spiritual needs. They are receptive to many different religions in the same time.

The non-Christians accept pluralism belief more easily than the Christians (including Catholics and Protestants). Religious belief in multi-religions relations reveals to us the believers' desire to look for what they need from different religions in both their content and form. To some extent, it also shows the characteristics of pantheism of the ancient Vietnamese people.

\section{CONCLUSION}

Religious pluralism is one of the modern religious movements. It is the development tendency of almost all world religions. Pluralism is becoming obviously and undeniably dominant in the Vietnamese religious life today in the integration with world religions. Under the impact of this pluralism process, the Vietnamese religions experience many changes, both internal and external.

Vietnam's religion itself contains elements of religious pluralism. Vietnamese worshiping has demonstrated the essence of the native polytheism and also clearly reflects the process of national development. Every period has left its specific halmark on religion and the latter is integrated with the former. The innovation perspective and awareness of the Party and the State on religions, accompanied by the change of religious policy, has fostered more favorable conditions for the development of Vietnamese religions. Religious pluralism is one of the basic characteristics and is a universal phenomenon of religions in Vietnam. This characteristic is based on the high amalgams of Vietnamese. The amalgam is the basic factor to make pluralism. Vietnam is one of the typical countries of amalgam religion.

Migration is one of the reasons cited which create religious pluralism. Since the ancient times up to now, the Vietnamese religions has been strongly influenced by the migration process. Migration, one of the elements that make religion spread from one region to another, is the primary factor that makes up the cultural and geopolitical identity of Vietnamese religions.

Religious pluralism environment brings about favorable conditions for the flourishing development of new religious movements in Vietnam. New religious movements share the characteristic of valuing individuality in its harmonious relation with the society. The new religious movement exists in the small groups of a few dozen, a few hundred, or a few tens of thousands of followers at most and have simple 
organization, flexible mode of operation, easily performative ritual practices, and suitable to people with low education and low income. The appearance of new religious movements is an inevitable phenomenon but brings disturbance to both religious life and social life.

Indeed, the religious life of Vietnam today shows that Vietnam now has high religious needs. This is reflected both in the religious believers and non-believers and expressed through the needs of ancestor worship, the wish to participate in the rituals of the traditional religions, visiting religious places such as churches, temples... This religious demand has brought about the revival and growth for Vietnam's religions recently and will continue to orientate the development favorable to the Vietnamese religions in the coming time.

About religious beliefs, religious behavioral indicators in Vietnam show that Vietnamese believers have deep religious belief and their belief bear traditional features. This is the fundamental difference between religion in Vietnam and that in many countries. From the social perspective, it raises a series of issues, especially the role and influence of religion on the society. Currently, the issue of religious social networks, social funding of religion and religious organizations in Vietnam are still left open. Succeeding in fostering high religious beliefs, a religion will have certain impacts on the society through the system of religious social funding or religious social network.

Polytheistic/pantheistic belief is becoming a trend getting stronger and stronger. Religious believers express their religious beliefs with various religious objects. In particular, although traditional characters have always been respected, pluralism has gradually appeared and gradually been accepted from many different angles by the Christians (including both Catholics and Protestants). This is one of the main characteristics of the religious landscape of Vietnam for the time being.

\section{NOTES}

1.This article came out of the project "Religious Pluralism in Vietnam Present Days - Theory and Practices" sponsored by National Foundation for Science and Technology Development (NAFOSTED).

2. The informants for these two surveys were divided into two groups: Christians (including Catholics and Protestants) and non-Christian (including Buddhism, traditional religions and non-religious people). This is a limitation of both surveys. However, these surveys were the first national ones on religions, so we have no other choice but to use these data to reflect the people's of religious beliefs in that period. There is a specific separation between the religious groups in other surveys that the author refer to in this article.

\section{R E F E R E N C E S}

Communist Party. 1991. Communist Party Article. Hanoi: National Political Publishing House.

Communist Party. 2017. Program of building the country in the transition time to socialism. 
Hanoi: Vietnam Communist Party Electronic Newspaper.

Dang Nghiem Van. 2001. Lý lu-n vÁ tôn giáo và tình hình tôn giáo $ß V i C ̧ t ~ N a m$ (theory on religion and religious circumstance in Vietnam). Hanoi: National Political Publishing House.

Diana L. Eck, 2. (2006). What is pluralism. Harvard University: Pluralism project. http:// pluralism.org/pages/pluralism/what_is_pluralism. Accessed: January 9, 2013.

Government Religious Affair. 2008. Survey of new religious movements in our country today, and proposal for solutions.

Hansen, Peter. 2010. North migration: Catholic refugees from North Vietnam and their role in the Republic of South Vietnam, 1954-1959, thematic: look back at the war 1954-1975. Talawas Magazine.

Hick, John. 2005. Religious pluralism and Islam. Lecture delivered to the Institute for Islamic Culture and Thought, Tehran (February 2005).

Massanari R. L. 1998. The pluralism of American "religious pluralism." Journal of Church and State, 40, 589-601.

Mattia Ricardi. 2016. Niezsche pluralism about consciousness. British Journal for the History of Philosophy, 132-154.

Nguyen Thi Minh Ngoc. 2016. Religiou Pluralism in Vietnam - theory and practical issues. Camau: Phuong Dong Publishing House.

Social Republic of Vietnam. 2013. Constitution. Hanoi: Law Electronic Library.

Wong, Wai Yip. 2012. Reconstructing John Hick's theory of religious pluralism: A Chinese folklore perspective. A Doctoral Philosophy dissertation. Theological and Religion Department, University of Birmingham.

Submitted: 13 February 2018; revised: 28 October 2019

Philosophia: International Journal of Philosophy

ISSN 2244-1875

Vol. 21, No. 1, January 2020 